\title{
Clonal Evolution of MEK/MAPK Pathway Activating Mutations in a Metastatic Colorectal Cancer Case
}

\author{
KAISA I. LEHTOMAKI ${ }^{1,2}$, LAURA I. LAHTINEN ${ }^{3}$, NINA RINTANEN $^{3}$, TEIJO KUOPIO ${ }^{3}$, IVANA KHOLOVA ${ }^{1,4}$, \\ RAMI MAKELA ${ }^{5}$, JUHA K. RANTALA ${ }^{5,6}$, PIRKKO-LIISA KELLOKUMPU-LEHTINEN ${ }^{1,2}$ and JUHA KONONEN ${ }^{3,7}$ \\ ${ }^{1}$ Faculty of Medicine and Health Technology, Tampere University, Tampere, Finland; \\ ${ }^{2}$ Tays Cancer Center, Tampere University Hospital, Tampere, Finland; \\ ${ }^{3}$ Central Finland Central Hospital, Jyväskylä, Finland; \\ ${ }^{4}$ Pathology, Fimlab Laboratories, Tampere, Finland; \\ ${ }^{5}$ Misvik Biology Ltd, Turku, Finland; \\ ${ }^{6}$ University of Sheffield, Sheffield, U.K.; \\ ${ }^{7}$ Docrates Cancer Center, Helsinki, Finland
}

\begin{abstract}
Background/Aim: The aim of this study was to examine clonal heterogeneity, to test the utility of liquid biopsy in monitoring disease progression and to evaluate the usefulness of ex vivo drug screening in a BRAF L597Q-mutated colorectal cancer (CRC) patient developing metastases during adjuvant therapy. Materials and Methods: Next generation sequencing $(N G S)$ and droplet digital PCR (ddPCR) were performed in samples from tumor tissues and liquid biopsies. Live cancer cells from a metastatic lesion were used in ex vivo drug sensitivity assays. Results: We found evidence of continued dependence of MEK/MAPK pathway activation, but different activating mutations in primary tumor and metastases. Liquid biopsy based BRAF L597Q ddPCR testing was a sensitive personalized biomarker predicting the rise of clinically aggressive metastatic disease. Ex vivo drug sensitivity assays with BRAF L597Q mutated cells showed response to MEK/MAPK targeted therapies. Conclusion: The rare BRAF L597Q mutation may be associated with aggressive tumor behavior in CRC. Liquid biopsy can be used to capture clinically relevant tumor features.
\end{abstract}

Understanding oncogenic drivers and molecular pathways promoting cancer development, progression and drug resistance is crucially important for precision oncology. As

This article is freely accessible online.

Correspondence to: Kaisa Lehtomäki, MD, Tays Cancer Center, Tampere University Hospital, Central Hospital, PO BOX 2000, FI33521 Tampere, Finland. Tel: +35 8405665805, +35 8331164524, e-mail: kaisa.lehtomaki@tuni.fi

Key Words: Colorectal cancer, liquid biopsy, ctDNA, BRAFnonV600E mutations, MEK/MAPK pathway, ex vivo drug screening. tissue-based molecular pathology analyses are subject to sampling bias, provide only a snapshot of tumor heterogeneity, and cannot be obtained repeatedly, liquid biopsies are suggested as an alternative to tissue-based analytics. Circulating cell-free tumor DNA (ctDNA) assays have been shown to capture many of the clinically relevant molecular features of cancer. However, it is still unclear how the presence of rare variants should be interpreted and whether sensitivity of ctDNA assays is sufficient for detection of actionable alterations when tumor burden is low (1-3).

In recent years, it has become clear that MEK/MAPKpathway is frequently activated in the pathogenesis of colorectal cancer (CRC) (4). The hotspot BRAF mutation V600E leads to very high and constitutive BRAF kinase activity and sustained MAPK pathway signaling.

The prevalence of the $B R A F \mathrm{~V} 600 \mathrm{E}$ mutation is $5-10 \%$ in metastatic colorectal cancer (mCRC) and it is a biomarker for poor prognosis (5). In BRAF V600E-mutant mCRC, patients median overall survival was only 10.4 months compared to 34.7 months in patients without this mutation (6). Increasing use of comprehensive tumor genomic profiling with next generation sequencing (NGS) technology has led to the detection of many $B R A F$ nonV600E mutations. Their prevalence in $\mathrm{mCRC}$ is reported to range from $1.6 \%$ to $5.1 \%$ (7-11). The BRAF V600E mutation still represents $60 \%$ to $80 \%$ of all $B R A F$-mutations $(11,12)$.

Clinical and prognostic implications of rare $B R A F$ mutations are largely unknown. Based on in vitro kinase activity data, $B R A F$-mutations can be classified into activating, intermediate activating and impaired activity subgroups, as compared to wild type- $B R A F(13,14)$. These data indicate that there are different types of $B R A F$ mutations, not all leading to a similar phenotype. Until now (14), little attention has been devoted to the functional 
characterization of rare mutations and their potential implications in the treatment of CRC.

Today, multiple BRAF-directed targeted therapies have been adopted into standard clinical practice. Unlike melanoma (15), BRAF and MEK-inhibitors used as a monotherapy show modest responses in BRAF V600E mCRC. In metastatic melanoma the response rate is up to $50 \%$, whereas only dismal 5\% response rates are reported in mCRC. However, combining EGFR-antibody with BRAFMEK-inhibitor doublet in BRAF V600E mutant mCRC patients finally resulted in an overall response rate of $48 \%$ for the binimetinib-encorafenib-cetuximab triplet. This led to the first FDA-approval for BRAF-inhibitors alone or in combinations in BRAF-mutated mCRC (16).

Here, we describe the molecular analysis and ex vivo functional characterization of a $B R A F$ L597Q-mutated colorectal cancer patient that developed metastatic disease during standard adjuvant therapy.

\section{Materials and Methods}

Case history. A 74-year-old female with no significant past medical history presented with severe anaemia (Hemoglobin $58 \mathrm{~g} / \mathrm{l}$ ). Colonoscopy biopsy samples revealed an adenocarcinoma located in the ascending colon. No unequivocal metastases were observed in computer tomography (CT) scan and preoperative carcinoembryonic antigen (CEA) was low $(3.1 \mu \mathrm{g} / \mathrm{l})$. Elective hemicolectomy was performed in February 2017. Histological examination revealed a grade II adenocarcinoma with lymphatic invasion, and lymph node status 3/16, staging pT3N1b. An adjuvant therapy with planned eight cycles of capecitabine-oxaliplatin (CAPOX) was initiated. A peritoneal lesion was found in a CT-scan 2 months after primary surgery and after the first chemotherapy cycle. Retrospective review showed that this lesion was detectable also in the preoperative CT scan. Nevertheless, this lesion was not metabolically active in the fludeoxyglucose $\left({ }^{18} \mathrm{~F}\right)$ positron emission tomography-computed tomography (PET-CT) scan 6 months after the surgery and showed no growth tendency. Instead, the PET-CT scan demonstrated a new metabolically active lymph node in the para-aortal area. After the seventh cycle of CAPOX (7 months after primary surgery) the active lymph node was removed and histologically verified as metastatic adenocarcinoma. One month later a new lesion in the right ovary was detected in CT with the same histology. During severe abdominal pain period, a metastasis infiltrating vena cava and multiple pulmonary metastases were detected. No further chemotherapy was initiated due to the rapid progression and patient deterioration. She died about a year after the initial diagnosis of colon cancer.

Study design. The patient was recruited in a prospective study that is designed for colorectal cancer patients resected with curative intent in Tampere University Hospital in Finland. The study was approved by the ethics committee of Tampere University Hospital (R15085) and the patient provided written informed consent. The trial identifier is NCT03189576. The drug sensitivity and resistance testing were implemented within another clinical trial recruiting in Central Finland Health Care District (DNRO 3U/2015).
Blood samples for ctDNA and CEA were planned to be collected preoperatively ( $0-3$ weeks before), at 4 weeks and every 3 months up to 2 years and every 6 months up to 3 years or until trial withdrawal or death. Altogether, five plasma samples were obtained from this patient before her death.

Algorithm for classifying ctDNA status. Plasma collection: Peripheral whole blood $(2 \times 10 \mathrm{ml})$ was collected into Vacuette Blood Collection Tubes (Bio-Greiner GmbH, Kremsmünster, Austria). Plasma was separated by centrifugation for $10 \mathrm{~min}$ at $1,100 \times \mathrm{g}$. Separated plasma was then stored at $-70^{\circ} \mathrm{C}$ until cfDNA extraction.

DNA extraction from plasma: Plasma cfDNA was extracted from $4 \mathrm{ml}$ of blood plasma using QIAamp Circulating Nucleic Acid Kit (Qiagen, Hilden, Germany). Extraction was performed according to the protocol provided by the kit manufacturer.

DNA extraction from tissue samples: DNA was extracted from representative FFPE tissue sections with QIAamp DNA FFPE Tissue Kit (Qiagen) according to the protocol provided by the kit manufacturer.

NGS: Qiaseq Human Comprehensive Cancer Panel (Qiagen) including 275 cancer related genes was used to prepare NGS amplicon gene library according to the protocol provided by kit manufacturer. Unique molecular identifiers (UMI) were used to tag individual DNA strands. Sequencing was performed with Illumina NextSeq500 instrument (Illumina, San Diego, CA, USA) according to standard protocol. Data was demultiplexed and fastq files created with bcl2fastq software (Illumina). The data was processed in CLC Biomedical Genomics Workbech (Qiagen) with workflow provided by Qiagen and using $\mathrm{Hg} 19$ human reference genome to call the gene variants. Gene annotations were performed according to the vcf files in OmnomicsNGS software (Euformatics, Espoo, Finland).

Droplet digital PCR: To detect the mutation BRAF c.1790T>A (p.Leu597Gln), droplet digital PCR (ddPCR) testing was performed in cfDNA samples. PCR mix contained $5 \mu \mathrm{l}$ cfDNA, $1 \times$ ddPCR Supermix for probes (no UTP; Bio-Rad, Hercules, CA, USA), $1 \times$ target (FAM) and wild-type (HEX) primers/probes (Bio-Rad), 2 U Hae III (New England Biolabs, Ipswich MA, USA) and water in a $20 \mu \mathrm{l}$ volume. Droplets were then prepared with QX200 Droplet Generator (Bio-Rad) and then the reactions were subjected to PCR cycling. The PCR cycling included a $95^{\circ} \mathrm{C}$ enzyme activation step for $10 \mathrm{~min}$ followed by 40 cycles of a two-step cycling protocol $\left(94^{\circ} \mathrm{C}\right.$ for $30 \mathrm{sec}$ and $55^{\circ} \mathrm{C}$ for $1 \mathrm{~min}$ ) and finally a $10 \mathrm{~min}$ enzyme inactivation step at $98^{\circ} \mathrm{C}$. The ramp rate between these steps was slowed to $2^{\circ} \mathrm{C} / \mathrm{sec}$. After PCR, the droplets were counted using QX200 Droplet Reader (Bio$\mathrm{Rad}$ ) and data analysis was performed with QuantaSoft software (BioRad). Each sample was prepared in duplicates. Mutation positive and negative samples were prepared as controls for test performance.

Drug sensitivity and resistance testing. A sample of metachronous para-aortal lymph node metastasis was dissected into three pieces by a pathologist: 1) formalin fixed sample for histological evaluation, 2) liquid nitrogen frozen sample for sequencing and 3) fresh tissue for drug testing.

For drug screening, tumour sample was rinsed with cold Hank's balanced salt solution (HyClone HBSS GEHealthCare Life Sciences, Marlborough, MA, USA) and dissected into $1 \mathrm{~mm} 3$ pieces with scalpel. Pieces were further digested enzymatically into a uniform cell suspension by incubating for $2.5 \mathrm{~h}$ in HBSS with $1 \mathrm{U} / \mathrm{ml}$ Dispase (Corning Bedford, MA, USA), after which the enzyme was inactivated by repeated washing and centrifugation of cells in RPMI- 
1640 cell culture medium (Lonza Ltd, Basel, Switzerland) supplemented with 5\% FCS (Gibco by Life Technologies, Waltham, MA, USA). Cells were seeded on ready-made 384-well drug plates that contained altogether 146 FDA-approved and investigational drugs in four different concentrations. The ex vivo drug screening library drugs were purchased from a commercial vendor (Cat no L1300, Selleck Chemicals, Houston, TX, USA). Cells were incubated for 5 days in the presence of drugs in four 2-fold dilutions with $5 \mu \mathrm{M}$ as the highest concentration. DMSO (Amresco Inc., Solon, OH, USA) only samples were used as negative control, $5 \mu \mathrm{M}$ Staurosporin (Fisher Scientific, Waltham, MA, USA) as cell death control and 2 $\mu \mathrm{M}$ Aphidicolin (MP Biomedicals, Santa Ana, CA, USA) was used for normalization of growth rate. Cell viability was measured by using a CellTiter-Glo reagent (CTG, Promega Corporation, Madison, WI, USA) and a luminescence reader (Labrox, Turku, Finland). The drug response data were analysed with Microsoft Excel using the normalized growth rate inhibition (GR) approach, which yields perdivision metrics for drug potency $(17,18)$. Absolute $\mathrm{IC}_{50}$ values were calculated with GraphPad Prism 7 software using a non-linear curve fit equation modified using previously described parameters (19).

Drug sensitivity testing (cell line derived from metachronous paraaortal lymph node metastasis). Adherent cell line derived from primary sample was cultured in RPMI-1640 medium (Lonza) containing $5 \%$ FCS (Gibco)+1\% L-glutamine (Gibco)+1\% Penicillin-Streptomycin (Gibco). Cells were seeded on a 384multiwell plate (2000 cells/ well) and were allowed to adhere and grow for 8 days before the addition of drugs. Wells were aspirated and drug dilutions were added on cells, which were then incubated at $37^{\circ} \mathrm{C}$ in a $5 \% \mathrm{CO}_{2}$ incubator for 5 days. Viability of cells was detected with a luminescence based CTG-assay. Mean results of normalized data from three parallel wells are shown. All experiments were performed two independent times in triplicate. Drugs used in drug combination tests were obtained from the National Cancer Institute (NCI)/Division of Cancer Treatment and Diagnosis (DCTD)/Developmental Therapeutics Program (DTP) repository (Rockville, MD, USA). Combination index (CI) which defines drug synergism $(\mathrm{CI}<1)$ and antagonism $(\mathrm{CI}>1)$ was calculated with Microsoft Excel from replicate, fixed-ratio, dose escalation experiments using the Chou and Talalay method (20). CI values were reported at $50 \%$ inhibitory values $\left(\mathrm{CI}_{50}\right)$.

\section{Results}

Mutational analysis. Targeted sequencing of the primary tumor revealed multiple somatic mutations (Table I, Figure 1). KRAS G13D has established clinical significance and guided therapy choices in this case. Co-occurrence of a KRAS mutation with BRAF F595L was detected in the primary tumor sample. Sequencing of the whole blood sample revealed no germline mutations.

Sequencing of the synchronous locoregional lymph node metastasis revealed a different assembly of somatic mutations (Table I, Figure 1). A BRAF L597Q had replaced the BRAF F595L and the KRAS G13D mutation had disappeared. In addition, nine other somatic mutations were found. The mutational landscape of metachronous para-aortal lymph node resembled the synchronous locoregional lymph node at the time of primary operation with only exception in SMAD4. A high concordance between mutations in these two lymph node metastases was detected in a plasma sample taken 9 months after primary surgery. The same driver mutations were observed in this liquid biopsy sample.

Ovarian metastasis revealed mutations in concordance with mutations found in the primary tumor: a $B R A F$ F595L mutation with KRAS G13D mutation (Table I, Figure 1).

Other known somatic mutations were found in CRC tissue samples in genes such as MAP2K4, MAP2K2, APC, AMER1, BCOR, BLM, AKT1, HIST1H3B, SMAD4, ASXL1 and CCNE1 (Table I, Figure 1).

Droplet digital PCR. Serial plasma samples $(\mathrm{N}=5)$ were tested for driver mutation, BRAF L597Q, with ddPCR. The ctDNA for BRAF L597Q was found in 4 out of the 5 time points (Figure 2).

Targeted drug testing. Viable tumor cells were successfully extracted and cultured from the metachronous para-aortal lymph node metastasis sample taken 7 months after primary surgery. These cells containing the BRAF L597Q mutation were assayed for response to various drugs and drug combinations ex vivo (Figures 3 and 4). The most effective single-agent compound was the MEK-inhibitor, trametinib, with an $\mathrm{IC}_{50}$ of $0.69 \mu \mathrm{M}$. Also, the MEK1/2-inhibitor, AZD6244, and the pan-EGFR-inhibitor, AZD8931, showed activity in killing tumor cells with an $\mathrm{IC}_{50}$ of $1.40 \mu \mathrm{M}$ and $1.86 \mu \mathrm{M}$, respectively. These results were consistent with the clinical experience that metastatic disease was resistant to adjuvant therapy of CAPOX showing tumor response in vitro with an $\mathrm{IC}_{50}$ of $25.81 \mu \mathrm{M}$ for capecitabine and $11.11 \mu \mathrm{M}$ for oxaliplatin (Figure 3). The control tumor cells grew well without the presence of an active antitumor agent. Drugs active against MEK/MAPK pathway targets were tested alone or in combinations in the tumor cell line derived from the metachronous para-aortal lymph node metastasis sample. Trametinib showed activity alone with an $\mathrm{IC}_{50}$ of $1.664 \mu \mathrm{M}$. Cetuximab as a single agent showed only modest activity with an $\mathrm{IC}_{50}$ of $157.900 \mathrm{mg} / \mathrm{ml}$ but the combination showed synergism $\left(\mathrm{CI}_{50}=0.67\right)$ with an $\mathrm{IC}_{50}$ of $1.009 \mu \mathrm{M}$ for trametinib, $10.090 \mathrm{mg} / \mathrm{ml}$ for cetuximab (Figure 4A). Adding dabrafenib to cetuximab showed no benefit with an $\mathrm{IC}_{50}$ of $9.237 \mu \mathrm{M}$ for dabrafenib, $92.370 \mathrm{mg} / \mathrm{ml}$ for cetuximab $\left(\mathrm{CI}_{50}=1.07\right)$ (Figure 4B). Similarly, the combination dabrafenib-trametinib had no synergism in these experiments with an $\mathrm{IC}_{50}$ of $1.279 \mu \mathrm{M}$ for the combination and an $\mathrm{IC}_{50}$ of $1.244 \mu \mathrm{M}$ for trametinib only $\left(\mathrm{CI}_{50}=1.14\right.$ ) (Figure $4 \mathrm{C}$ ).

\section{Discussion}

Results presented here emphasize multiple aspects of tumor heterogeneity. It has been established that the molecular 
Table I. Targeted sequencing. The mutations found in the primary tumor, in the locoregional synchronous lymph node metastasis, in the metachronous para-aortal lymph node metastasis and in the ovarian metastasis.

\begin{tabular}{|c|c|c|c|c|c|}
\hline & $\begin{array}{l}\text { Primary } \\
\text { tumor }\end{array}$ & $\begin{array}{l}\text { Ovarian } \\
\text { metastasis }\end{array}$ & $\begin{array}{c}\text { Synchronous } \\
\text { locoregional } \\
\text { metastatic } \\
\text { lymph node }\end{array}$ & $\begin{array}{c}\text { Metachronous } \\
\text { para-aortal } \\
\text { metastatic } \\
\text { lymph node }\end{array}$ & $\begin{array}{c}\text { Plasma sample } \\
9 \text { months } \\
\text { after primary } \\
\text { surgery }\end{array}$ \\
\hline & $\begin{array}{c}\text { Average } \\
\text { coverage } \\
641\end{array}$ & $\begin{array}{c}\text { Average } \\
\text { coverage } \\
630\end{array}$ & $\begin{array}{c}\text { Average } \\
\text { coverage } \\
50\end{array}$ & $\begin{array}{c}\text { Average } \\
\text { coverage } \\
1579\end{array}$ & $\begin{array}{c}\text { Average } \\
\text { coverage } \\
2273\end{array}$ \\
\hline \multicolumn{6}{|l|}{ BLM } \\
\hline $\begin{array}{l}\text { c. } 2287 \mathrm{C}>\mathrm{G} \text { p.Leu763Val } \\
\text { BRAF }\end{array}$ & $24.7 \%$ & $0.0 \%$ & $0.0 \%$ & $0.0 \%$ & $0.0 \%$ \\
\hline $\begin{array}{l}\text { c. } 1785 T>G \text { p.Phe } 595 \text { Leu } \\
\text { KRAS }\end{array}$ & $26.7 \%$ & $20.7 \%$ & $0.0 \%$ & $0.0 \%$ & $0.0 \%$ \\
\hline c.38G >A p.Gly13Asp & $26.2 \%$ & $4.4 \%$ & $0.0 \%$ & $0.0 \%$ & $0.0 \%$ \\
\hline $\begin{array}{l}\text { APC c.4393_4394delp.Ser1465TrpfsTer3 } \\
\text { MAP2K4 }\end{array}$ & $34.0 \%$ & $14.8 \%$ & $43.1 \%$ & $8.3 \%$ & $1.8 \%$ \\
\hline $\begin{array}{l}\text { c. } 328 \mathrm{C}>\mathrm{T} \text { p.Arg } 110 \mathrm{Ter} \\
\text { AMER1 }\end{array}$ & $35.7 \%$ & $15.2 \%$ & $42.5 \%$ & $19.1 \%$ & $2.0 \%$ \\
\hline $\begin{array}{l}\text { c. } 1591 \mathrm{C}>\mathrm{T} \text { p.Arg } 531 \mathrm{Ter} \\
\text { BCOR }\end{array}$ & $43.1 \%$ & $0.0 \%$ & $45.9 \%$ & $18.0 \%$ & $3.6 \%$ \\
\hline $\begin{array}{l}\text { c. } 1792 \mathrm{G}>\text { A p.Val598Met } \\
\text { SMAD4 }\end{array}$ & $11.5 \%$ & $0.0 \%$ & $26.9 \%$ & $13.1 \%$ & $2.4 \%$ \\
\hline $\begin{array}{l}\text { c. } 808 \mathrm{G}>\mathrm{T} \text { p.Gly270Ter } \\
\text { HIST1H3B }\end{array}$ & $0.0 \%$ & $0.0 \%$ & $0.0 \%$ & $16.5 \%$ & $2.1 \%$ \\
\hline $\begin{array}{l}\text { c. } 318 \mathrm{G}>\mathrm{C} \text {, p.Glu106Asp } \\
\text { CCNE1 }\end{array}$ & $0.0 \%$ & $0.0 \%$ & $26.2 \%$ & $13.1 \%$ & $1.4 \%$ \\
\hline $\begin{array}{l}\text { c. } 276 \mathrm{C}>\mathrm{G} \text { p.Cys } 92 \text { Trp } \\
\text { BRAF }\end{array}$ & $0.0 \%$ & $0.0 \%$ & $33.2 \%$ & $15.4 \%$ & $1.2 \%$ \\
\hline $\begin{array}{l}\text { c. } 1790 \mathrm{~T}>\mathrm{A}, \mathrm{p} . \text { Leu } 597 \mathrm{Gln} \\
\text { MAP2K2 }\end{array}$ & $0.0 \%$ & $0.0 \%$ & $42.5 \%$ & $15.9 \%$ & $3.2 \%$ \\
\hline $\begin{array}{l}\text { c.395G>A p.Gly132Asp } \\
\text { AKT1 }\end{array}$ & $0.0 \%$ & $0.0 \%$ & $30.7 \%$ & $16.3 \%$ & $2.8 \%$ \\
\hline $\begin{array}{l}\text { c.49G >A, p.Glu17Lys } \\
\text { BCOR }\end{array}$ & $0.0 \%$ & $0.0 \%$ & $43.0 \%$ & $17.1 \%$ & $2.2 \%$ \\
\hline $\begin{array}{l}\text { c.724G > T p.Glu242Ter } \\
\text { ASXL1 }\end{array}$ & $0.0 \%$ & $0.0 \%$ & $40.4 \%$ & $20.9 \%$ & $2.6 \%$ \\
\hline c. $2501 \mathrm{~A}>\mathrm{G}$ p.His834Arg & $0.0 \%$ & $0.0 \%$ & $0.0 \%$ & $0.0 \%$ & $3.2 \%$ \\
\hline
\end{tabular}

makeup of tumors evolves dynamically in response to treatment and correlates with disease progression (21). Here, we showed that the primary tumor and metastatic sites may show dependence on the same signaling pathway, but mutations in target genes may show heterogeneity. These results illustrate that currently dominating and therapeutically relevant clonality may not be accurately captured by relying on primary tumor samples as a tissue source for treatmentguiding molecular pathology analyses. CtDNA has been suggested to be useful as a surrogate marker for metabolically active, dominant cancer clones. Previous studies have shown good correlation of ctDNA alterations with tissue biopsies, particularly in EGFR-driven cancers (22-24). There are also promising results in the non-metastatic, postoperative setting $(25,26)$. These findings have led to the suggestion that identification of these mutations in patient's blood, enables characterization of molecular heterogeneity, molecular residual disease and tumor evolution in real time. Results presented here illustrate that this approach is feasible.

It can be speculated that activating the MEK/MAPK pathway is crucial for colorectal cancer cell survival, yet different activating mutation combinations can result in a similar tumor phenotype. Interestingly, BRAF L597Q appeared to be the most suitable ctDNA biomarker for our patient. This ctDNA was detected in preoperative samples, the amount rapidly decreased after surgery and resurgence predicted clinical relapse.

For this patient BRAF L597Q ctDNA was a more sensitive biomarker than CEA or radiological imaging with CT. This is in agreement with the suggestion that ctDNA could work 
A

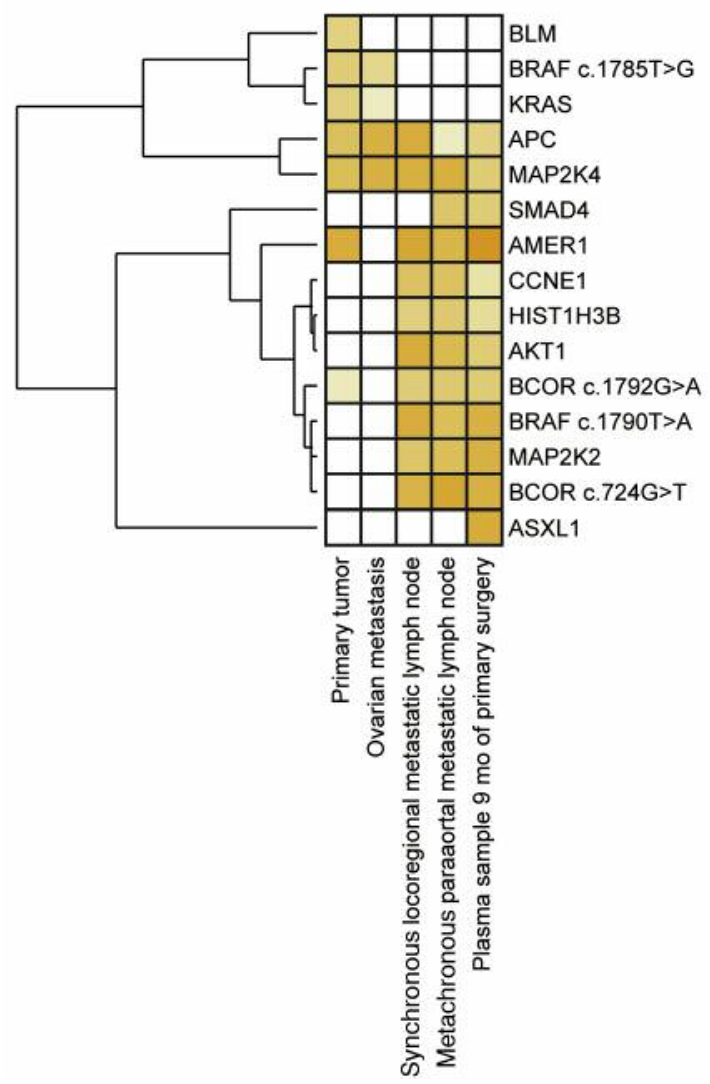

B

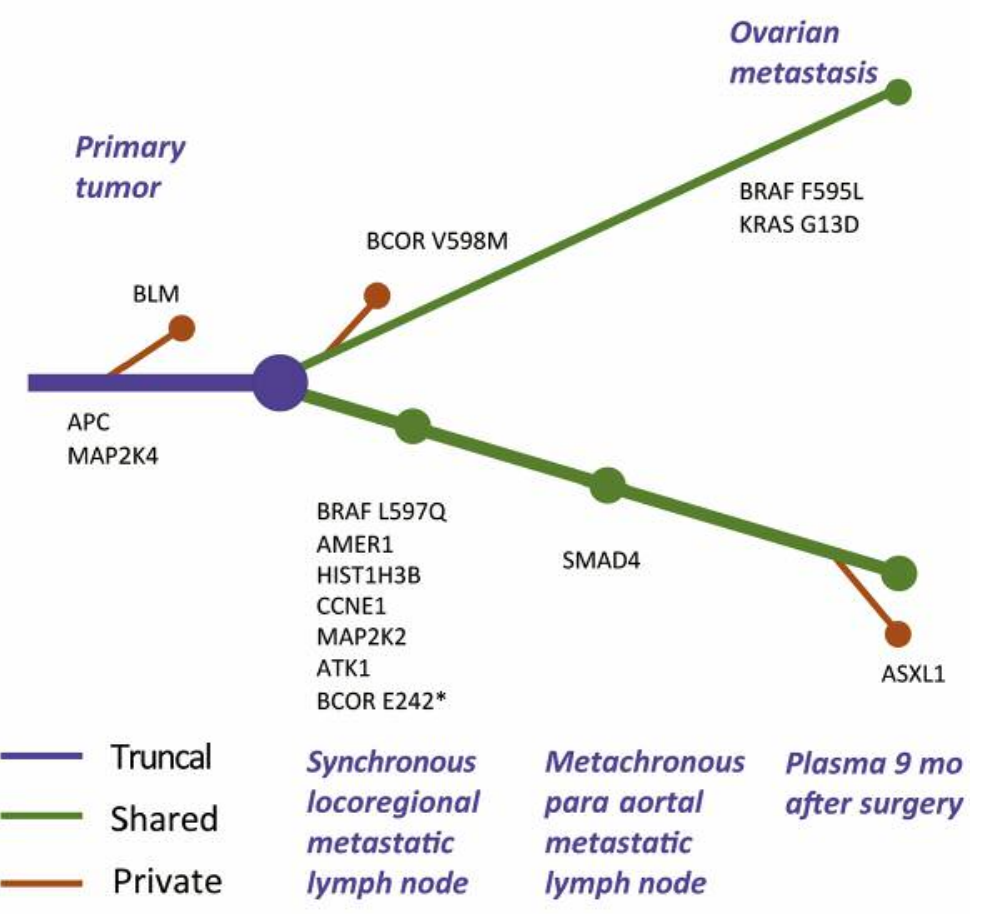

Figure 1. Nonsynonymous mutations in the primary tumor, metastatic lesions and plasma represented in a heat map (A) and in branched evolution (B).

as an early indicator of tumor dynamics and serve to guide treatment strategies by revealing dominant tumor clonality. In vitro evidence also points to the role of BRAF L597Q as an oncogenic driver mutation since it has been described to be sufficient for MEK/MAPK pathway activation but to a lesser extent compared to $B R A F \operatorname{V600E}(13,27,28)$. There are no previous functional data available regarding this rare mutation in CRC. BRAF L597Q has been described in studies cataloguing BRAF mutations $(27,29,30)$. The prevalence of $B R A F$ L597Q mutation has been highest in melanoma, occurring at $4.1 \%$ frequency in two melanoma series $(27,31)$.

It is interesting to note that KRAS G13D mutation was lost in the metastatic sites with the BRAF L597Q mutation but retained in ovarian metastasis that contained the $B R A F$ F595L mutation. Co-operation of the BRAF F595L and KRAS is consistent with the reported literature $(32,33)$. $B R A F$ V600E and KRAS-mutations tend not to be expressed together and the mutual exclusivity is speculated to be due to senescence (34). In contrast, weak and intermediate kinase activity $B R A F$ nonV600E mutant tumors are more likely to occur with concomitant KRAS-mutations $(6,10,12,32,33$, $35,36)$.

Other mutations found in primary tumor and metastatic sites (APC, AMER1, SMAD4, MAP2K2, MAP2K4, AKT1, BCOR and BLM) have all been previously described somatic mutations in CRC $(4,12,37-41) . A P C$ and $M A P 2 K 2$ mutations appeared to be present in all samples suggesting that these were truncal mutations in this cancer, whereas variability was observed for other mutations suggesting their subclonal nature.

Mutations appear to be enriched in key oncogenic signaling pathway target genes. It has been shown that new mutations in the EGFR gene conferring drug resistance may be detected when evolutionary pressure in the form of EGFR TKI therapy or EGFR monoclonal antibody suppresses drugsensitive clones $(42,43)$. These findings stress the importance of a system biology-based approach for cancer therapy, i.e. establishing the major molecular switch that promotes tumor survival and focusing on therapeutically shutting down this cascade. In the context of CRC, our results point to the key role of MEK/MAPK pathway as an oncogenic switch. 
A

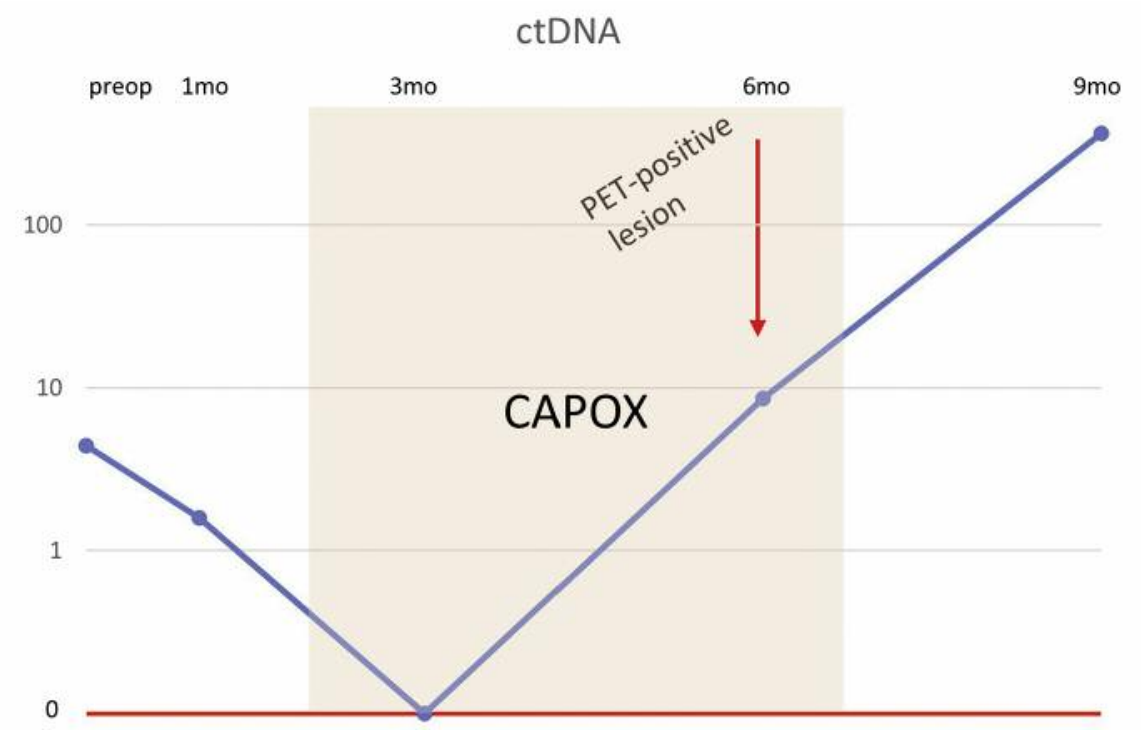

B

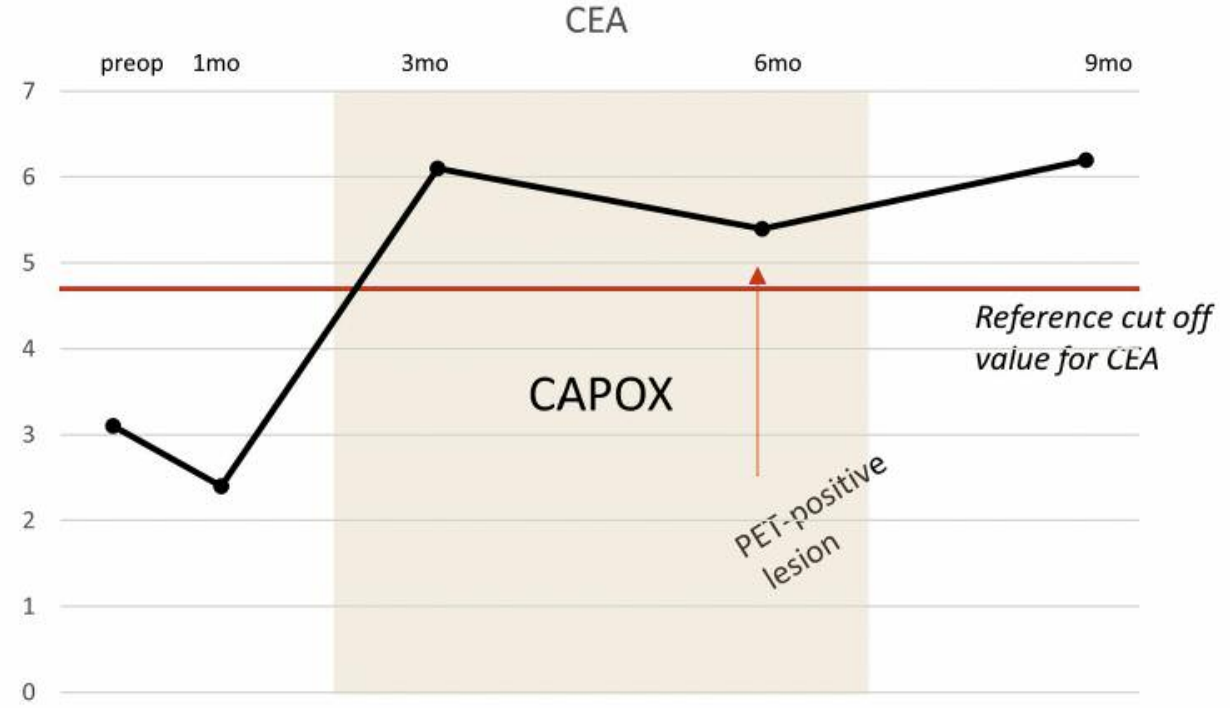

Figure 2. Blood based biomarker dynamics illustrating that for this patient BRAF L597Q ctDNA appeared to be more sensitive biomarker for relapse than CEA. Blood samples for ctDNA (A) and CEA (B) were collected preoperatively (1 week before), and at 1, 3, 6 and 9 months after primary surgery. Arrow indicates the time point when a new metabolically active lymph node in para-aortal area was detected in fludeoxyglucose (18F) positron emission tomography-computed tomography (PET-CT) scan. The y-axis is in logarithmic scale in figure (A).

The best strategy for MEK/MAPK pathway inhibition in mCRC remains to be determined. BRAF inhibitor monotherapy as well as dual blockage of the MEK/MAPK pathway have had limited efficacy in mCRC (44-49). One reason for treatment failure seems to be the negative feedback network that leads to reactivation of MAPK signaling following treatment with a BRAF inhibitor. In CRC, this mechanism of resistance seems to be at least partially mediated via EGFR, while the whole underlying cascade has not yet been discovered $(46,48)$. Combining a third target, EGFR- inhibition, to the BRAF-MEK-inhibitor- doublet in $B R A F$ V600E mutant patients resulted in a response rate of $21 \%$ with dabrafenib-trametinib-panitumumab triplet (50). Recently, binimetinib-encorafenib-cetuximab triplet resulted in an overall response rate of $48 \%$ and led to FDA-approval (16).

It has been suggested that one approach to improve personalized oncology is to utilize patient-derived live cancer cells, cancer cell clusters or organoid models to directly screen for optimally active drugs and drug combinations. Here, we employed this strategy to test effectiveness of a 

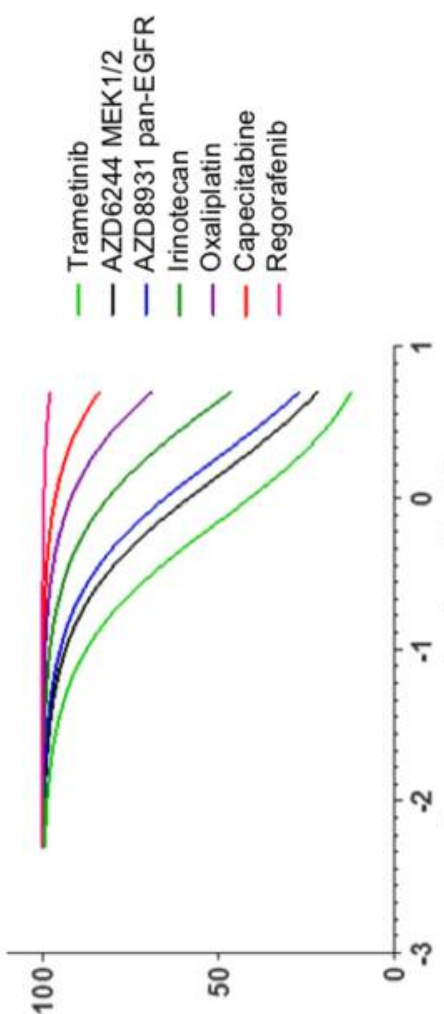

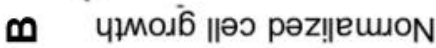
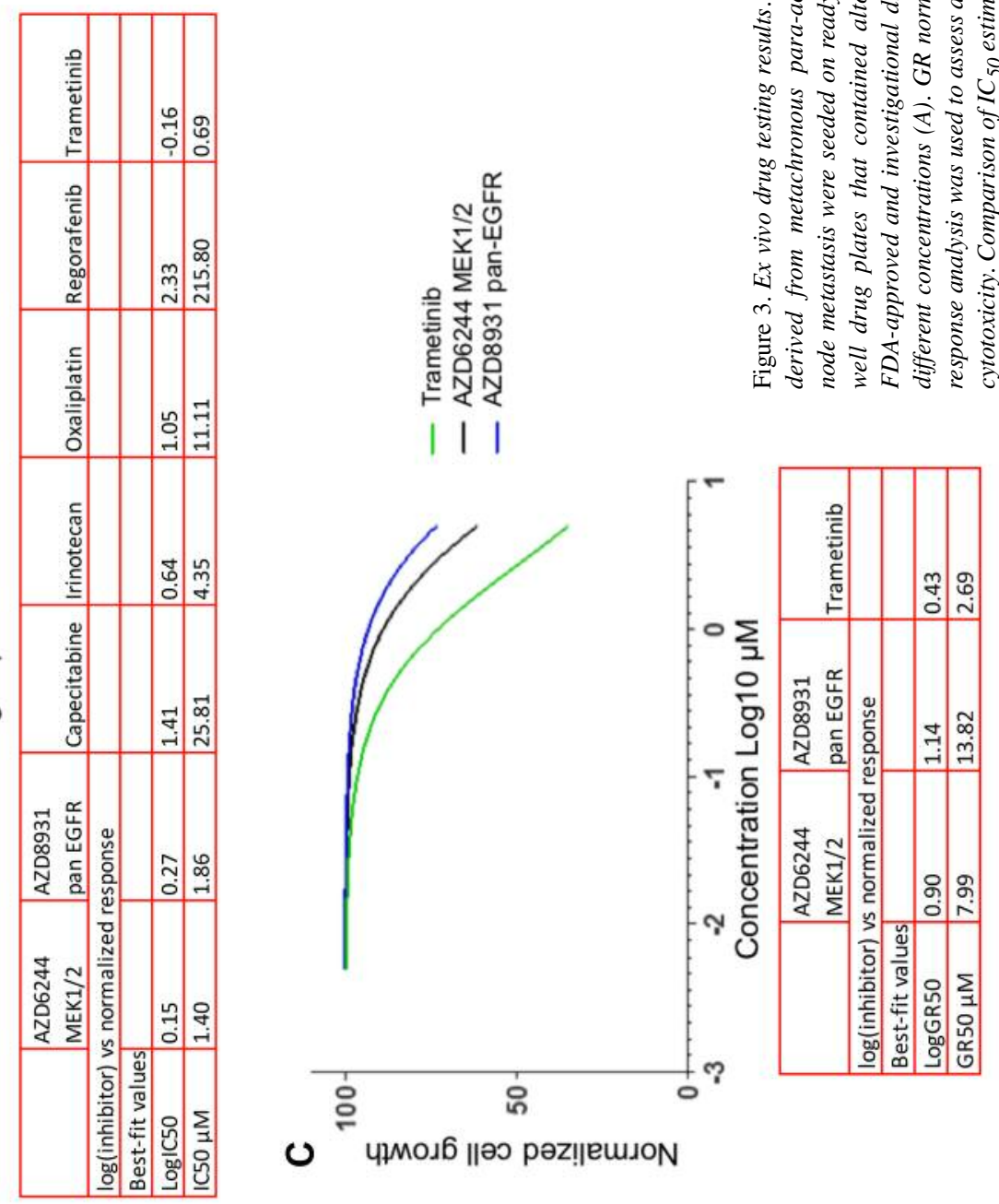
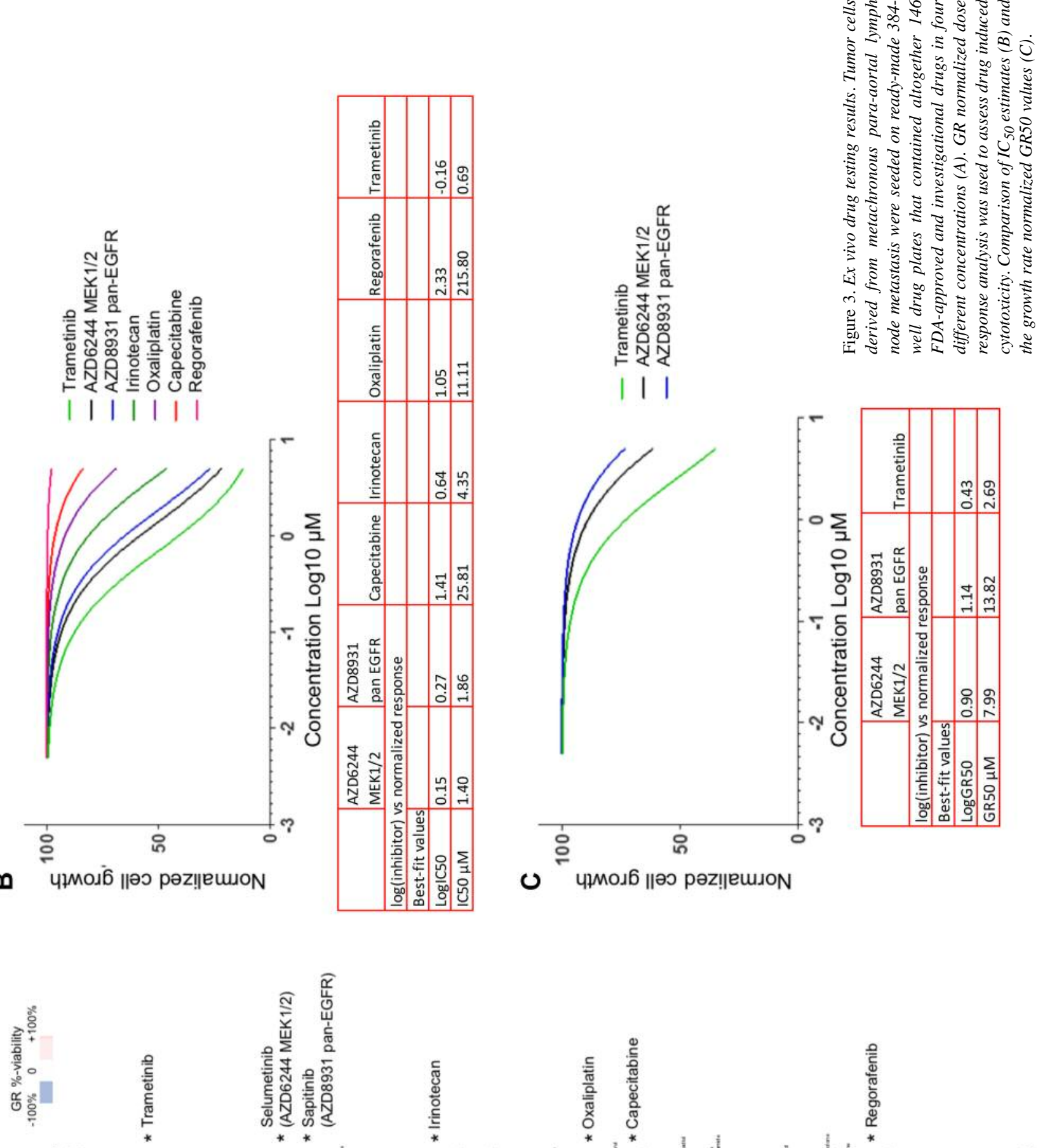

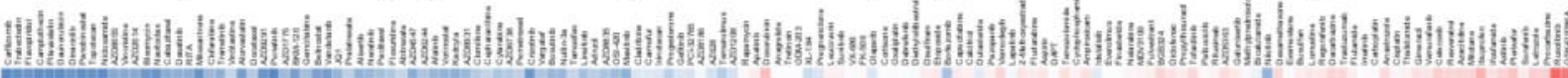

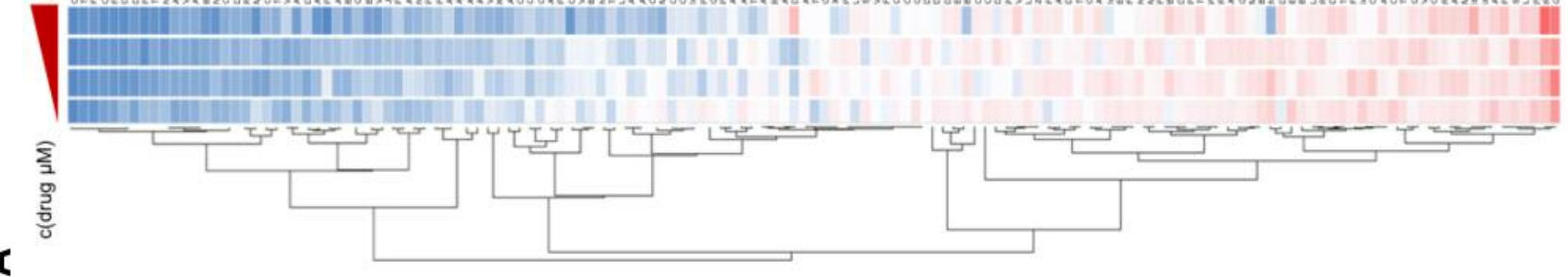




\section{A}

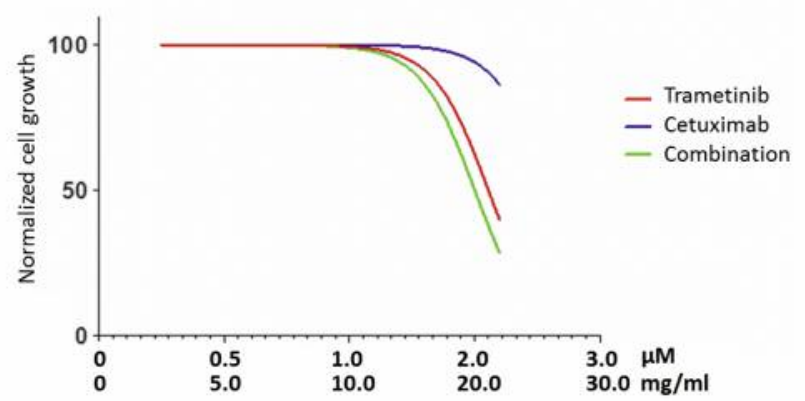

\begin{tabular}{|c|c|c|c|c|c|}
\hline \multicolumn{3}{|c|}{ log(inhibitor) vs. normalized response } & \multicolumn{2}{|c|}{ Combination } & \multirow[b]{2}{*}{$\mathrm{Cl} 150$} \\
\hline & Trametinib & Cetuximab & Trametinib & Cetuximab & \\
\hline & $\mu \mathrm{M}$ & $\mathrm{mg} / \mathrm{ml}$ & $\mu \mathrm{M}$ & $\mathrm{mg} / \mathrm{ml}$ & \\
\hline LoglC50 & 0.221 & 2.198 & 0.004 & 1.004 & \\
\hline IC50 & 1.664 & 157.900 & 1.009 & 10.090 & 0.67 \\
\hline
\end{tabular}

\section{B}

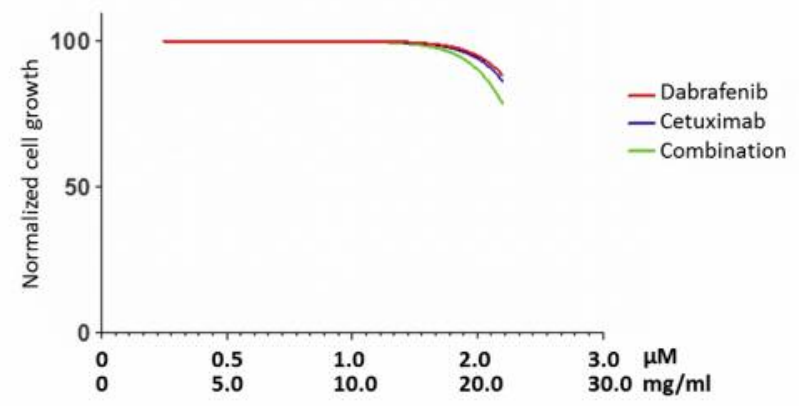

\begin{tabular}{|c|c|c|c|c|c|}
\hline \multicolumn{3}{|c|}{ log(inhibitor) vs. normalized response } & \multicolumn{2}{|c|}{ Combination } & \multirow[b]{2}{*}{$\mathrm{Cl} 50$} \\
\hline & Dabrafenib & Cetuximab & Dabrafenib & Cetuximab & \\
\hline & $\mu \mathrm{M}$ & $\mathrm{mg} / \mathrm{ml}$ & $\mu \mathrm{M}$ & $\mathrm{mg} / \mathrm{ml}$ & \\
\hline LogIC50 & 1.278 & 2.198 & 0.966 & 1.966 & \\
\hline IC50 & 18.950 & 157.900 & 9.237 & 92.370 & 1.07 \\
\hline
\end{tabular}

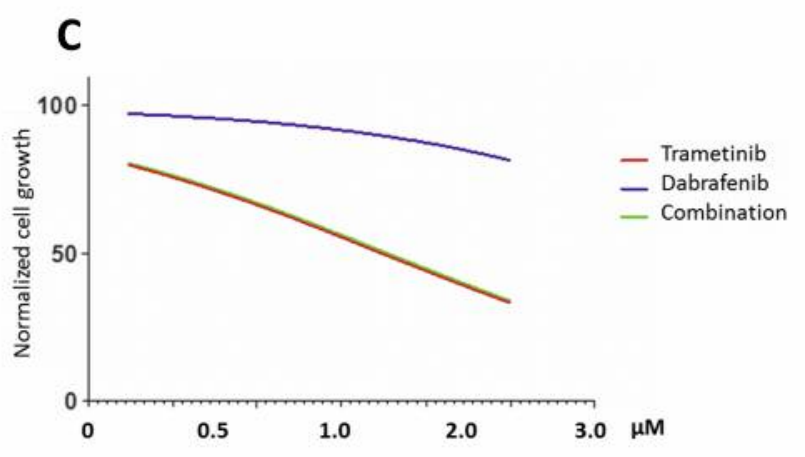

\begin{tabular}{|c|c|c|c|c|}
\hline \multicolumn{3}{|c|}{ log(inhibitor) vs. normalized response } & \multirow[t]{2}{*}{ Combination } & \multirow[b]{2}{*}{$\mathrm{C} 150$} \\
\hline & Trametinib & Dabrafenib & & \\
\hline & $\mu \mathrm{M}$ & $\mu \mathrm{M}$ & $\mu \mathrm{M}$ & \\
\hline LogIC50 & 0.095 & 1.041 & 0.107 & \\
\hline IC50 & 1.244 & 11.000 & 1.279 & 1.14 \\
\hline
\end{tabular}

Figure 4. Targeted ex vivo drug testing. Tumor cell line derived from the metachronous para-aortal lymph node metastasis was tested with drugs specially directed via MEK/MAPK pathway, alone or in combinations: trametinib-cetuximab (A), dabrafenib-cetuximab (B) and trametinibdabrafenib $(C)$.

panel of cancer drugs on patient-derived tumor cells carrying $B R A F$ L597Q driver mutation. Importantly, these cells were resistant to fluorouracil + oxaliplatin regimen recapitulating clinical tumor behavior. A MEK-inhibitor, trametinib was the most effective compound as single agent with an $\mathrm{IC}_{50}$ of $0.69 \mu \mathrm{M}$. An EGFR-inhibitor, cetuximab, alone showed very modest activity, but the combination of trametinib-cetuximab resulted in quantitative synergy $\left(\mathrm{CI}_{50}=0.67\right)$ (22) with decreased $\mathrm{IC}_{50}$ of both drugs. In contrast, a $B R A F$-inhibitor, dabrafenib, appeared ineffective. Our results are in concordance with previous findings showing that intermediate activating $B R A F$-mutations signal as dimers and do not respond to BRAF-inhibitors as single agents. EGFR
+ MEK inhibition is probably required to target such $B R A F$ mutations (14).

Combination of NGS and ex vivo testing appears to be a promising strategy for hypothesis-generating experiments in precision oncology. We suggest to perform NGS sequencing in the primary tumor to derive a list of driver genetic alterations and create affordable PCR-assayable personalized biomarkers to monitor treatment response with liquid biopsies. At the time of progression, extended molecular profiling could be used to analyze clonal evolution and detect novel genetic alterations. These data could then be used to engineer personalized drug panels to be tested with ex vivo assays on cancer cells derived from tissue biopsies. 


\section{Conflicts of Interest}

The Authors declare that no competing interests exist regarding this study.

\section{Author's Contributions}

KL, PL-KL, JK: study design, oversight, data analysis; LL: NGS experiments and data analysis; NR, JKR, RM: ex vivo drug testing; TK, IK: pathology workup; All Authors contributed to manuscript writing and accepted the final manuscript.

\section{Acknowledgements}

National Cancer Institute (NCI)/Division of Cancer Treatment and Diagnosis (DCTD)/Developmental Therapeutics Program (DTP) (http://dtp.cancer.gov) is acknowledged as source of the Oncology Drugs Set. This work has also been supported in part by AZ-SLLKI open innovation grant \#18122013 and Seppo Nieminen's fund (grant \# 160627). TheAuthors would like to thank Tuula Vierikko for providing assistance for reviewing radiological images.

\section{References}

1 Heitzer E, Perakis S, Geigl JB and Speicher MR: The potential of liquid biopsies for the early detection of cancer. NPJ Precis Oncol 1: 36, 2017. PMID: 29872715. DOI: 10.1038/s41698-0170039-5

2 Morris V, Dasari A and Kopetz S: Can circulating tumor DNA in early-stage colorectal cancer be more than a prognostic biomarker? JAMA Oncol, 2019. PMID: 31070713. DOI: 10.1001/jamaoncol.2019.0503

3 Antoniotti C, Pietrantonio F, Corallo S, De Braud F, Falcone A and Cremolini C: Circulating tumor DNA analysis in colorectal cancer: From dream to reality. JAMA Oncol, 2019. PMID: 31621801. DOI: 10.1001/jamaoncol.2019.3616

4 Mármol I, Sánchez-de-Diego C, Pradilla Dieste A, Cerrada E and Rodriguez Yoldi MJ: Colorectal carcinoma: A general overview and future perspectives in colorectal cancer. Int J Mol Sci 18: 197, 2017. PMID: 28106826.

5 Korphaisarn $\mathrm{K}$ and Kopetz S: BRAF-directed therapy in metastatic colorectal cancer. Cancer J 22: 175-178, 2016. PMID: 27341594. DOI: 10.1097/PPO.0000000000000189

6 Tran B, Kopetz S, Tie J, Gibbs P, Jiang Z-Q, Lieu CH, Agarwal A, Maru DM, Sieber O and Desai J: Impact of BRAF mutation and microsatellite instability on the pattern of metastatic spread and prognosis in metastatic colorectal cancer. Cancer 117: 46234632, 2011. PMID: 21456008.

7 Cremolini C, Di Bartolomeo M, Amatu A, Antoniotti C, Moretto R, Berenato R, Perrone F, Tamborini E, Aprile G, Lonardi S, Sartore-Bianchi A, Fontanini G, Milione M, Lauricella C, Siena S, Falcone A, de Braud F, Loupakis F and Pietrantonio F: BRAF codons 594 and 596 mutations identify a new molecular subtype of metastatic colorectal cancer at favorable prognosis. Ann Oncol 26: 2092-2097, 2015. PMID: 26153495.

8 Shinozaki E, Yoshino T, Yamazaki K, Muro K, Yamaguchi K, Nishina T, Yuki S, Shitara K, Bando H, Mimaki S, Nakai C, Matsushima K, Suzuki Y, Akagi K, Yamanaka T, Nomura S, Fujii
S, Esumi H, Sugiyama M, Nishida N, Mizokami M, Koh Y, Abe Y, Ohtsu A and Tsuchihara K: Clinical significance of BRAF nonV600E mutations on the therapeutic effects of anti-EGFR monoclonal antibody treatment in patients with pretreated metastatic colorectal cancer: the Biomarker Research for anti-EGFR monoclonal Antibodies by Comprehensive C. Br J Cancer 117: 1450-1458, 2017. PMID: 28972961. DOI: 10.1038/bjc.2017.308

9 Shen Y, Wang J, Han X, Yang H, Wang S, Lin D and Shi Y: Effectors of epidermal growth factor receptor pathway: the genetic profiling ofKRAS, BRAF, PIK3CA, NRAS mutations in colorectal cancer characteristics and personalized medicine. PLoS One 8: e81628, 2013. PMID: 24339949.

10 Ciardiello F, Normanno N, Maiello E, Martinelli E, Troiani T, Pisconti S, Giuliani F, Barone C, Cartenì G, Rachiglio AM, Montesarchio V, Tonini G, Rizzi D, Cinieri S, Bordonaro R, Febbraro A, De Vita F, Orditura M, Fenizia F, Lambiase M, Rinaldi A, Tatangelo F, Botti G and Colucci G: Clinical activity of FOLFIRI plus cetuximab according to extended gene mutation status by next-generation sequencing: findings from the CAPRI-GOIM trial. Ann Oncol 25: 1756-1761, 2014. PMID: 24942275.

11 Jones JC, Renfro LA, Al-Shamsi HO, Schrock AB, Rankin A, Zhang BY, Kasi PM, Voss JS, Leal AD, Sun J, Ross J, Ali SM, Hubbard JM, Kipp BR, McWilliams RR, Kopetz S, Wolff RA and Grothey A: Non-V600 BRAF mutations define a clinically distinct molecular subtype of metastatic colorectal cancer. J Clin Oncol 35: 2624-2630, 2017. PMID: 28486044.

12 Yaeger R, Chatila WK, Lipsyc MD, Hechtman JF, Cercek A, Sanchez-Vega F, Jayakumaran G, Middha S, Zehir A, Donoghue MTA, You D, Viale A, Kemeny N, Segal NH, Stadler ZK, Varghese AM, Kundra R, Gao J, Syed A, Hyman DM, Vakiani E, Rosen N, Taylor BS, Ladanyi M, Berger MF, Solit DB, Shia J, Saltz L and Schultz N: Clinical sequencing defines the genomic landscape of metastatic colorectal cancer. Cancer Cell 33: 125136.e3, 2018. PMID: 29316426. DOI: 10.1016/j.ccell.2017.12.004

13 Wan PTC, Garnett MJ, Roe SM, Lee S, Niculescu-Duvaz D, Good VM, Jones CM, Marshall CJ, Springer CJ, Barford D, Marais R and Cancer Genome Project: Mechanism of activation of the RAF-ERK signaling pathway by oncogenic mutations of B-RAF. Cell 116: 855-867, 2004 PMID: 15035987. DOI: 10.1016/S0092-8674(04)00215-6

14 Dankner M: Targeted therapy for colorectal cancers with nonV600 BRAF mutations: perspectives for precision oncology. JCO Precis Oncol: 1-12, 2018. DOI: 10.1200/PO.18.00195

15 Hauschild A, Grob J-J, Demidov L V, Jouary T, Gutzmer R, Millward M, Rutkowski P, Blank CU, Miller WH, Kaempgen E, Martín-Algarra S, Karaszewska B, Mauch C, Chiarion-Sileni V, Martin A-M, Swann S, Haney P, Mirakhur B, Guckert ME, Goodman V and Chapman PB: Dabrafenib in BRAF-mutated metastatic melanoma: a multicentre, open-label, phase 3 randomised controlled trial. Lancet (London, England) 380: 358365, 2012 PMID: 22735384. DOI: 10.1016/S0140-6736(12)60868$\mathrm{X}$

16 Van Cutsem E, Huijberts S, Grothey A, Yaeger R, Cuyle P-J, Elez E, Fakih M, Montagut C, Peeters M, Yoshino T, Wasan H, Desai J, Ciardiello F, Gollerkeri A, Christy-Bittel J, Maharry K, Sandor V, Schellens JHM, Kopetz S and Tabernero J: Binimetinib, encorafenib, and cetuximab triplet therapy for patients with BRAF V600E-mutant metastatic colorectal cancer: safety lead-in results from the phase III BEACON Colorectal 
Cancer Study. J Clin Oncol, 2019. PMID: 30892987. DOI: 10.1200/JCO.18.02459

17 Hafner M, Niepel M, Chung M and Sorger PK: Growth rate inhibition metrics correct for confounders in measuring sensitivity to cancer drugs. Nat Methods 13: 521-527, 2016. PMID: 27135972. DOI: 10.1038/nmeth.3853

18 Hafner M, Niepel M and Sorger PK: Alternative drug sensitivity metrics improve preclinical cancer pharmacogenomics. Nat Biotechnol 35: 500-502, 2017. PMID: 28591115. DOI: 10.1038/ nbt. 3882

19 Sebaugh JL: Guidelines for accurate $\mathrm{EC}_{50} / \mathrm{IC}_{50}$ estimation. Pharm Stat 10: 128-134, 2011. PMID: 22328315. DOI: 10.1002/pst.426

20 Chou TC: Drug combination studies and their synergy quantification using the Chou-Talalay method. Cancer Res 70: 440-446, 2010. PMID: 20068163. DOI: 10.1158/00085472.CAN-09-1947.

21 Siravegna G, Marsoni S, Siena S and Bardelli A: Integrating liquid biopsies into the management of cancer. Nat Rev Clin Oncol 14: 531-548, 2017. PMID: 28252003. DOI: 10.1038/ nrclinonc. 2017.14

22 Grasselli J, Elez E, Caratù G, Matito J, Santos C, Macarulla T, Vidal J, Garcia M, Viéitez JM, Paéz D, Falcó E, Lopez Lopez C, Aranda E, Jones F, Sikri V, Nuciforo P, Fasani R, Tabernero J, Montagut C, Azuara D, Dienstmann R, Salazar R and Vivancos A: Concordance of blood- and tumor-based detection of RAS mutations to guide anti-EGFR therapy in metastatic colorectal cancer. Ann Oncol 28: 1294-1301, 2017. PMID: 28368441. DOI: $10.1093 /$ annonc/mdx 112

23 Bachet JB, Bouché O, Taieb J, Dubreuil O, Garcia ML, Meurisse A, Normand C, Gornet JM, Artru P, Louafi S, Bonnetain F, ThirotBidault A, Baumgaertner I, Coriat R, Tougeron D, Lecomte T, Mary F, Aparicio T, Marthey L, Taly V, Blons H, Vernerey D and Laurent-Puig P: RAS mutation analysis in circulating tumor DNA from patients with metastatic colorectal cancer: the AGEO RASANC prospective multicenter study. Ann Oncol 29: 12111219, 2018. PMID: 29438522. DOI: 10.1093/annonc/mdy061.

24 Siravegna G, Mussolin B, Buscarino M, Corti G, Cassingena A, Crisafulli G, Ponzetti A, Cremolini C, Amatu A, Lauricella C, Lamba S, Hobor S, Avallone A, Valtorta E, Rospo G, Medico E, Motta V, Antoniotti C, Tatangelo F, Bellosillo B, Veronese S, Budillon A, Montagut C, Racca P, Marsoni S, Falcone A, Corcoran RB, Di Nicolantonio F, Loupakis F, Siena S, Sartore-Bianchi A and Bardelli A: Clonal evolution and resistance to EGFR blockade in the blood of colorectal cancer patients. Nat Med 21: 795-801, 2015. PMID: 26030179. DOI: 10.1038/nm.3870.

25 Wang Y, Li L, Cohen JD, Kinde I, Ptak J, Popoli M, Schaefer J, Silliman N, Dobbyn L, Tie J, Gibbs P, Tomasetti C, Kinzler KW, Papadopoulos N, Vogelstein B and Olsson L: Prognostic Potential of circulating tumor DNA measurement in postoperative surveillance of nonmetastatic colorectal cancer. JAMA Oncol, 2019. PMID: 31070668. DOI: 10.1001/jamaoncol.2019.0512

26 Reinert T, Henriksen TV, Christensen E, Sharma S, Salari R, Sethi H, Knudsen M, Nordentoft I, Wu H-T, Tin AS, Heilskov Rasmussen M, Vang S, Shchegrova S, Frydendahl Boll Johansen A, Srinivasan R, Assaf Z, Balcioglu M, Olson A, Dashner S, Hafez D, Navarro S, Goel S, Rabinowitz M, Billings P, Sigurjonsson S, Dyrskjøt L, Swenerton R, Aleshin A, Laurberg S, Husted Madsen A, Kannerup A-S, Stribolt K, Palmelund Krag S, Iversen LH, Gotschalck Sunesen K, Lin C-HJ, Zimmermann BG and Lindbjerg Andersen $\mathrm{C}$ : Analysis of plasma cell-free DNA by Ultradeep sequencing in patients with stages I to III colorectal cancer. JAMA Oncol, 2019. PMID: 31070691. DOI:10.1001/jamaoncol.2019.0528

27 Dahlman KB, Xia J, Hutchinson K, Ng C, Hucks D, Jia P, Atefi M, Su Z, Branch S, Lyle PL, Hicks DJ, Bozon V, Glaspy JA, Rosen N, Solit DB, Netterville JL, Vnencak-Jones CL, Sosman JA, Ribas A, Zhao Z and Pao W: BRAF(L597) mutations in melanoma are associated with sensitivity to MEK inhibitors. Cancer Discov 2: 791-797, 2012. PMID: 22798288. DOI: 10.1158/2159-8290.CD-12-0097.

28 Bahadoran P, Allegra M, Le Duff F, Long-Mira E, Hofman P, Giacchero D, Passeron T, Lacour J-P and Ballotti R: Major clinical response to a BRAF inhibitor in a patient with a BRAF L597R-mutated melanoma. J Clin Oncol 31: e324-326, 2013. PMID: 23715574.

29 Heinzerling L, Kühnapfel S, Meckbach D, Baiter M, Kaempgen E, Keikavoussi P, Schuler G, Agaimy A, Bauer J, Hartmann A, Kiesewetter F and Schneider-Stock R: Rare BRAF mutations in melanoma patients: implications for molecular testing in clinical practice. Br J Cancer 108: 2164-2171, 2013. PMID: 23579220. DOI: $10.1038 /$ bjc.2013.143

30 Carlino MS, Haydu LE, Kakavand H, Menzies AM, Hamilton $\mathrm{AL}, \mathrm{Yu} \mathrm{B}, \mathrm{Ng} \mathrm{CC}$, Cooper WA, Thompson JF, Kefford RF, O'Toole SA, Scolyer RA and Long GV: Correlation of BRAF and NRAS mutation status with outcome, site of distant metastasis and response to chemotherapy in metastatic melanoma. Br J Cancer 111: 292-299, 2014. PMID: 24918823. DOI: $10.1038 /$ bjc. 2014.287

31 Beadling C, Heinrich MC, Warrick A, Forbes EM, Nelson D, Justusson E, Levine J, Neff TL, Patterson J, Presnell A, McKinley A, Winter LJ, Dewey C, Harlow A, Barney O, Druker BJ, Schuff KG and Corless CL: Multiplex mutation screening by mass spectrometry. J Mol Diagnostics 13: 504-513, 2011. PMID: 21726664. DOI:

10.1016/j.jmoldx.2011.04.003

32 Kordes M, Röring M, Heining C, Braun S, Hutter B, Richter D, Geörg C, Scholl C, Gröschel S, Roth W, Rosenwald A, Geissinger E, von Kalle C, Jäger D, Brors B, Weichert W, Grüllich C, Glimm H, Brummer T and Fröhling S: Cooperation of BRAF(F595L) and mutant HRAS in histiocytic sarcoma provides new insights into oncogenic BRAF signaling. Leukemia 30: 937-946, 2016. PMID: 26582644. DOI: 10.1038/leu.2015.319

33 Ikenoue T, Hikiba Y, Kanai F, Tanaka Y, Imamura J, Imamura T, Ohta M, Ijichi H, Tateishi K, Kawakami T, Aragaki J, Matsumura M, Kawabe T and Omata M: Functional analysis of mutations within the kinase activation segment of B-Raf in human colorectal tumors. Cancer Res 63: 8132-8137, 2003. PMID: 14678966.

34 Cisowski J and Bergo MO: What makes oncogenes mutually exclusive? Small GTPases 8: 187-192, 2017. PMID: 27416373. DOI: $10.1080 / 21541248.2016 .1212689$

35 Deshwar A, Margonis GA, Andreatos N, Barbon C, Wang J, Buettner S, Wagner D, Sasaki K, Beer A, Løes IM, Pikoulis E, Damaskos C, Garmpis N, Kamphues K, He J, Kaczirek K, Poultsides G, Lønning PE, Mischinger HJ, Aucejo FN, Kreis ME, Wolfgang CL and Weiss MJ: Double KRAS and BRAF mutations in surgically treated colorectal cancer liver metastases: an international, multi-institutional case series. Anticancer Res 38(5): 2891-2895, 2018. PMID: 29715113. DOI: 10.21873/ anticanres. 12535

36 Thomas RK, Baker AC, DeBiasi RM, Winckler W, LaFramboise $\mathrm{T}$, Lin WM, Wang M, Feng W, Zander T, MacConaill LE, Lee 
JC, Nicoletti R, Hatton C, Goyette M, Girard L, Majmudar K, Ziaugra L, Wong K-K, Gabriel S, Beroukhim R, Peyton M, Barretina J, Dutt A, Emery C, Greulich H, Shah K, Sasaki H, Gazdar A, Minna J, Armstrong SA, Mellinghoff IK, Hodi FS, Dranoff G, Mischel PS, Cloughesy TF, Nelson SF, Liau LM, Mertz K, Rubin MA, Moch H, Loda M, Catalona W, Fletcher J, Signoretti S, Kaye F, Anderson KC, Demetri GD, Dummer R, Wagner S, Herlyn M, Sellers WR, Meyerson M, Garraway LA and Garraway LA: High-throughput oncogene mutation profiling in human cancer. Nat Genet 39: 347-351, 2007. PMID: 17293865. DOI: $10.1038 / \mathrm{ng} 1975$

37 Testa U, Pelosi E and Castelli G: Colorectal cancer: genetic abnormalities, tumor progression, tumor heterogeneity, clonal evolution and tumor-initiating cells. Med Sci (Basel, Switzerland) 6, 2018. PMID: 29652830. DOI: 10.3390/medsci 6020031

38 Lee S, Park HY, Kang SY, Kim SJ, Hwang J, Lee S, Kwak SH, Park KS, Yoo HY, Kim WS, Kim JI and Ko YH: Genetic alterations of JAK/STAT cascade and histone modification in extranodal NK/T-cell lymphoma nasal type. Oncotarget 6: 17764-17776, 2015. PMID: 25980440.

39 Haigis KM: Molecular pathogenesis of colorectal cancer. Springer, 2013.

40 Katoh M: Functional and cancer genomics of ASXL family members. Br J Cancer 109: 299-306, 2013. PMID: 23736028. DOI: $10.1038 / \mathrm{bjc} .2013 .281$

41 Ohshima K, Hatakeyama K, Nagashima T, Watanabe Y, Kanto K, Doi Y, Ide T, Shimoda Y, Tanabe T, Ohnami S, Ohnami S, Serizawa M, Maruyama K, Akiyama Y, Urakami K, Kusuhara M, Mochizuki T and Yamaguchi K: Integrated analysis of gene expression and copy number identified potential cancer driver genes with amplification-dependent overexpression in 1,454 solid tumors. Sci Rep 7: 641, 2017. PMID: 28377632. DOI: 10.1038/s41598-017-00219-3

42 Pao W, Miller VA, Politi KA, Riely GJ, Somwar R, Zakowski MF, Kris MG and Varmus $\mathrm{H}$ : Acquired resistance of lung adenocarcinomas to gefitinib or erlotinib is associated with a second mutation in the EGFR kinase domain. PLoS Med 2: e73, 2005. PMID: 15737014. DOI: 10.1371/journal.pmed.0020073

43 Misale S, Yaeger R, Hobor S, Scala E, Janakiraman M, Liska D, Valtorta E, Schiavo R, Buscarino M, Siravegna G, Bencardino K, Cercek A, Chen CT, Veronese S, Zanon C, Sartore-Bianchi A, Gambacorta M, Gallicchio M, Vakiani E, Boscaro V, Medico E, Weiser M, Siena S, Di Nicolantonio F, Solit D and Bardelli A: Emergence of KRAS mutations and acquired resistance to anti-EGFR therapy in colorectal cancer. Nature 486: 532-536, 2012. PMID: 22722830. DOI: 10.1038/nature 11156

44 Kopetz S, Desai J, Chan E, Hecht JR, O’Dwyer PJ, Maru D, Morris V, Janku F, Dasari A, Chung W, Issa J-PJ, Gibbs P, James B, Powis G, Nolop KB, Bhattacharya S and Saltz L: Phase II pilot study of vemurafenib in patients with metastatic BRAFmutated colorectal cancer. J Clin Oncol 33: 4032-4038, 2015. PMID: 26460303. DOI: 10.1200/JCO.2015.63.2497
45 Corcoran RB, Atreya CE, Falchook GS, Kwak EL, Ryan DP, Bendell JC, Hamid O, Messersmith WA, Daud A, Kurzrock R, Pierobon M, Sun P, Cunningham E, Little S, Orford K, Motwani M, Bai Y, Patel K, Venook AP and Kopetz S: Combined BRAF and MEK inhibition with dabrafenib and trametinib in BRAF V600-mutant colorectal cancer. J Clin Oncol 33: 4023-4031, 2015. PMID: 26392102.

46 Prahallad A, Sun C, Huang S, Di Nicolantonio F, Salazar R, Zecchin D, Beijersbergen RL, Bardelli A and Bernards R: Unresponsiveness of colon cancer to BRAF(V600E) inhibition through feedback activation of EGFR. Nature 483: 100-103, 2012. PMID: 22281684. DOI: $10.1038 /$ nature 10868

47 Hyman DM, Puzanov I, Subbiah V, Faris JE, Chau I, Blay J-Y, Wolf J, Raje NS, Diamond EL, Hollebecque A, Gervais R, ElezFernandez ME, Italiano A, Hofheinz R-D, Hidalgo M, Chan E, Schuler M, Lasserre SF, Makrutzki M, Sirzen F, Veronese ML, Tabernero $\mathrm{J}$ and Baselga $\mathrm{J}$ : Vemurafenib in multiple nonmelanoma cancers with BRAF V600 mutations. N Engl J Med 373: 726-736, 2015. PMID: 26287849.

48 Corcoran RB, Ebi H, Turke AB, Coffee EM, Nishino M, Cogdill AP, Brown RD, Della Pelle P, Dias-Santagata D, Hung KE, Flaherty KT, Piris A, Wargo JA, Settleman J, Mino-Kenudson $\mathrm{M}$ and Engelman JA: EGFR-mediated re-activation of MAPK signaling contributes to insensitivity of BRAF mutant colorectal cancers to RAF inhibition with vemurafenib. Cancer Discov 2: 227-235, 2012. PMID: 22448344.

49 Mao M, Tian F, Mariadason JM, Tsao CC, Lemos R, Dayyani F, Gopal YN V., Jiang Z-Q, Wistuba II, Tang XM, Bornman WG, Bollag G, Mills GB, Powis G, Desai J, Gallick GE, Davies MA and Kopetz S: Resistance to BRAF inhibition in BRAF-mutant colon cancer can be overcome with PI3K inhibition or demethylating agents. Clin Cancer Res 19: 657-667, 2013. PMID: 23251002. DOI: 10.1158/1078-0432.CCR-11-1446

50 Corcoran RB, André T, Atreya CE, Schellens JHM, Yoshino T, Bendell JC, Hollebecque A, McRee AJ, Siena S, Middleton G, Muro K, Gordon MS, Tabernero J, Yaeger R, O'Dwyer PJ, Humblet Y, De Vos F, Jung AS, Brase JC, Jaeger S, Bettinger S, Mookerjee B, Rangwala F and Van Cutsem E: Combined BRAF, EGFR, and MEK inhibition in patients with BRAFV600Emutant colorectal cancer. Cancer Discov 8: 428-443, 2018. PMID: 29431699.
Received September 21, 2019

Revised October 22, 2019

Accepted October 24, 2019 